\title{
Social Problems of Drug Use and Drug Policies
}

\author{
Joel Fort* \\ The welfare of the people has always been the alibi of tyrants.
}

Camus

I

\section{INTRODUCTION: DEFTNITIONS}

A RATIONAL DISCUSSION of the social problems relating to drug abuse requires accurate definitions of terms whose meanings are too often taken for granted, terms such as "drug," "use," and "abuse." The word "drug," which is so loosely bandied about by the mass media, police, and pohticians in connection with marijuana, LSD, and narcotics, actually applies to the whole range of mind-altering drugs, including alcohol, nicotine, and barbiturates, and to even larger families of drugs, including aspirin, antibiotics, and antihistamines. In medicine, the term "drug" applies to any biologically active substance affecting the brain or other bodily organs or tissues. Mind-altering or psychoactive drugs-those which primarily affect the mind or consciousness-include alcolıol, caffeine, nicotine (tobacco), barbiturates and other sedatives, amphetamines and other stimulants, tranquillizers, narcotics, LSD-type drugs, and marijuana. "Those who improperly define "drugs" commumicate, often deliberately, erroneous impressions to the public and to lawmakers.

Common parlance about the "use" of socially disapproved or illegal drugs usually conveys the impression that any or all use is abusive and constitutes addiction; conversely, references to socially approved drugs sucli as alcoliol and nicotine usually imply that almost all use, including abusive and addictive use, is normal. We must recognize that use of drugs in either category ranges from one-time or occasional use, on the one hand, to regular use-only some of this involving large or excessive quantities or daily use-on the other. Furthermore, only a few of the many mind-altering drugs, namely alcohol, barbiturates and other seda-

*B.A., 1948, M.D., 1954, Ohio State University; Lecturer, San Francisco State College and University of California Extension; creator and former Director, San Francisco Center for Special Problems; former Consultant on Drug Abuse, World Health Organization and United Nations.

1 Each of the mind-altering drugs should be referred to by name, e.g., "LSD" rather than "psychedehc" or "hallucinogen," and "marijuana" rather than "soft narcotic" or "mild psychedelic." On whether marijuana is properly classified (in laws, popular articles, and political speeches) as a narcotic, see W. EIDRIDGE, NARcotics AND THE LAW 1, 15 n.5, 139 (2d ed. 1967). 
tives, and narcotics, will, when used daily and excessively, lead to addiction, that is, physical dependence. Addiction means that the body cells adapt to the drug, that the user requires ever larger amounts to produce the same effect, and that an abrupt termination of drug usage produces an abstinence syndrome or withdrawal illness. Habituation-that is, psychological dependence-may result from using any of the drugs, including coffee, alcohol, nicotine, and marijuana. This condition exists when an individual becomes so psychologically accustomed to the drug that when it is no longer available he becomes ill at ease, restless, or irritable. Of course, even television viewing and other activities not in. volving drugs may produce habituation.

The term "drug abuse" refers to the use of a mind-altering drugusually chronic, excessive use-to an extent that interferes either with an individual's social or vocational adjustinent or with his health. This concept properly includes such things as drunk driving, cirrhosis of the liver due to alcoholism, barbiturate addiction, amphetamme psychosis, and a "bad" LSD "trip." Addiction is only a small part of the drug abuse picture. "Misuse" of mind-altering drugs refers to any nonspecific or nonmedicinal use of such drugs, including alcohol and nicotine.

The definition of what is or is not a "problem" is perhaps the most complex of all. For the most part, "problems" are artificially defined for use - often irrationally and for self-serving reasons-by opinion formers and rulemakers. Many of the things which we are told are drug "problems" are pseudoproblems; for example, the wrong drug or the wrong component of the cycle of use and control of a particular drug frequently is designated as a problem. On the other hand, some of the nost underemphasized aspects of drug use or control are serious problems. Laws enacted in a climate of ignorance and hysteria understandably create "problems" where they did not exist before.

\section{II}

\section{DRUG USE LAWS AND POLICLES}

There is considerable misunderstanding about drug policies, largely because our society has developed these policies in a very narrow, and oversimplified fashion. The drugs disapproved by society's "establishinent" or rule makers are dealt with in terms of criminal prohibitions accompanied by increasingly severe penalties for the user or possesser of such drugs. ${ }^{2}$ Such a policy is analogous to smashing a young child in the

\footnotetext{
2 See, e.g., INd. ANw. Stat. \& 10-3538 (Supp. 1967) (narcotic drugs); Mrss. Code ANN. § 6831-08 (Supp. 1967) (barbiturates and stimulants). Regardless sales of narcotics (including marijuana), the Indiana statute provides for penalties of 5-20 years and not more than $\$ 2,000$ for a first offense, and 20 years to life and not more than $\$ 5,000$ for subsequent
} 
face and throwing it out of the home for touching something it was not supposed to touch rather than recognizing that a wide-range of less destructive and more effective measures are available. In contrast, use of socially acceptable drugs such as alcohol and nicotine encounters little regulation, and what regulation there is often goes unenforced.

Present policies regarding alcohol and mcotine involve often unenforced laws against sale to, or use by, minors, ${ }^{3}$ inodest state and federal taxes, ${ }^{4}$ minimal restrictions on the lours during which alcohol can be served in public places, ${ }^{5}$ federal laws regulating production of alcohol, ${ }^{6}$ and a large body of laws against serving already intoxicated people ${ }^{7}$ or driving while intoxicated. ${ }^{8}$ Some counties in a few states pretend to maintain prohibition of alcohol. Policies relating to socially condemned drugs date back at least to the passage of the Harrison Anti-Narcotic Act ${ }^{9}$ in 1914 and include the fourteen year period of national alcohol prohibition, the Marihuana Tax Act of $1937,{ }^{10}$ state marijuana laws, ${ }^{11}$ the Narcotic Control Act of $1956,{ }^{12}$ the Federal Drug Abuse Control Amendments of $1965^{13}$ and state laws on LSD-type drugs. ${ }^{14}$

offenses; regarding possession, it provides for 2-10 years and not more than $\$ 1,000$ for a first offense, 5-20 years and not more than $\$ 2,000$ for subsequent offenses. Under the Mississippi law, both possession and sale are punishable by a fine of not more than $\$ 1,000$ and imprisonment for not more than 5 years for a first offense, a maximum fine of $\$ 3,000$ and a 5-10 year period of imprisonment for a second offense, and a maximum fine of $\$ 5,000$ and a 10-20 year period of imprisonment for a third offense. See generally Rosenthal, Dangerous Drug Legislation in the United States, Recommendations and Comments, 45 Texas L. REv. 1037, 1073, 1077 (1967).

3 E.g., Cat. Bus. \& Prof. Code $\S$ 25658-65 (West 1964) (alcohol); CaL. Pen. Code $\S 308$ (West 1955) (tobacco).

4 E.g., INT. REv. Cone of 1954, \$§ 5001, 5021-23, 5041, 5051, 5081, 5701 (taxes on distilled spirits, wine, beer, cigars, and cigarettes); CAI. REv. \& TAX CODE \$\$ 30101, 32151 (West Supp. 1966); id. § 32201 (West 1956) (taxes on distilled spirits, wine, beer, and cigarettes).

5 E.g., CaL. Pen. Code \$ 398 (West 1955).

${ }^{B}$ INT. Rev. Code of 1954, $\S 5001-692$.

7 E.g., CaI. Bus. \& Prof. Code $\$ 25602$ (West 1964).

8 E.g., CaI. Pen. Code $\$ 367$ d (West 1955).

9 Ch. 1, 38 Stat. 785 (now InT. Rev. Cone of 1954, §§ 4701-36).

10 Act of Aug. 2, 1937, ch. 553, 50 Stat. 551, as amended, INT. REv. Code of 1954, $\S \S 4741-62$.

11 E.g., compare CaI. Feattr \& SAFETY CoDe $\$ 11721$ with id. § 11001 (d) (West 1964). For a concise review of state marijuana legislation, see Rosenthal, supra note 2, at 1077 .

$12 \mathrm{Ch} .629,70$ Stat. 567 (codified in scattered sections of 21, 26 U.S.C.).

13 Pub. I. No. 89-74, 79 Stat. 226. For a description of the law see Rosenthal, supra note 2 , at 1051-62.

14 E.g., CaL. Heattri \& Safety Code $§ \S 11901,11910-16$ (West Supp. 1967); compare ARIz. REv. STAT. ANN. \$\$ 32-1964, 32-1975(B) (Supp. 1967) with id. \$\$ 32-1965 to -1968 (1956); compare N.Y. PEN. LAW \$\$ 220.00-.40 (McKinney 1967) with N.Y. MENTaI HYoreNe LAW \$ 229 (McKinney Supp. 1967). See generally Laughlin, LSD-25 and the Other Hallucinogens: A Pre-Reform Proposal, 36 Gro. WaSH. L. Rev. 23, 28 n.25 (1967). 
The American system of attempted control of drugs has been extremely unsuccessful and harmful; the use and abuse of mind-altering drugs has increased enormously in direct proportion with the imposition of severe criminal penalties on users. More potentially dangerous drugs (alcohol, heroin, nicotine, LSD, and amphetamines) and a greater diversity of substances are now being used to alter consciousness. Use has come to involve ever younger age groups and a greater diversity of socioeconomic classes. Tens of thousands of individuals have been branded as criminals and their hes ruined. The almost constant publicity given to various drugs by politicians and the drug police has, over a period of decades, greatly sensationalized substances such as heroin, marijuana, and LSD, thereby stimulating curiosity and magical expectations about drug usage. Beginning with the prohibition against alcolıol, the supply of illegal drugs lias been driven underground into the black market where it lias lielped to enrich and develop organized crime. Powerful and virtually uncontrolled bureaucracies established in local, state, and federal governnients liave developed new and more ineffective laws and have attacked every effort towards developing rational, humane, and effective policies. The selective enforcement of these status crimes-crimes without victims as they are sometimes called-and their emphasis on the user rather than on the profiteer involves tremendous hypocrisy and produces disrespect for the law and the police. The enforcement practices of drug police, such as the use of spies, informers, threats, bribes, and entrapment are basically un-American and immoral and lead to further disrespect for law enforcement.

America's drug control laws, including those directed against alcohol in the 1920's and the more recent ones concerning heroin, marijuana, and LSD, have consistently been enacted on the basis of anecdotal, unscientific, and illogical testimony adduced mainly from drug police and their political allies and received in a climate of lysteria willingly developed and reinforced by the mass media. Legislatures have heard almost no medical, sociological, or scientific testimony from either individuals or organizations before enacting these far-reaching laws. ${ }^{16}$ Moreover, with the possible exception of the relatively brief period of alcohol prohibition, there liave been no powerful financial or political interests defending either the users of these drugs or the drugs thenselves, a situation obviously conducive to the enactment of such laws.

15 See, e.g., Hearings on Traffic in, and Control of, Narcotics, Barbiturates, and Amphetamines, Before a Subcomm. of the House Comm. on Ways and Means, 84th Cong., 1st \& 2d Sess. (1957). 


\section{III}

\section{DRUG USE AND ABUSE: THE PATTERN AND ITS TMPLICATIONS}

Roughly eighty million people in the United States use nicotine, ${ }^{16}$ and probably as many use alcohol. ${ }^{17}$ Included in both categories are millions of persons under the age of twenty-one whose use of these drugs is ordinarily illicit and involves deliberate violations of the law, ${ }^{18}$ often with the same motives that accompany the use of less approved drugs sucli as niarijuana. Both alcoliol and nicotine are used by persons in all socioeconomic groups and in widely varying occupations. The causative relationship between the use of nicotine and hundreds of thousands of deaths and disabilities eacli year in the United States from lung cancer, lieart disease, liypertension, emphysema, and bronchitis is well establislied. ${ }^{19}$ There are an estimated 4.5 to 6.8 million alcoholics in the nation, ${ }^{20}$ and more in the San Francisco Bay Area alone than there are narcotic addicts in the entire country. ${ }^{21}$ At least twenty-five thousand deaths and more than a million severe injuries on the highways eacl year are associated with alcohol consumption; ${ }^{22}$ twenty percent of the people in state mental hospitals are there because of alcoholic brain disease; ${ }^{23}$ fifty percent of the people $\mathrm{m}$ prisons have committed their crimes in association with alcohol consumption; ${ }^{24}$ one-third of all arrests are for drunkenness, ${ }^{25}$ and probably as many as one-half are for alcoliol-related of-

${ }^{16}$ Lukas, The Drug Scene: Dependence Grows, N.Y. Times, Jan. 8, 1968, at 22, col. 2 [hereinafter cited as The Drug Scene].

17 Id. "It can be said that 68 percent of all American adults have had at least one drink within the past year. Twenty-two percent of the population report they have never tried an alcoholic beverage." Presment's Comm'N on Law ENForcendent aNd ADMMNISTRation of JUSTICE, TASK Force Report: Drunkenness 29-30 (1967) [hereinafter cited as Task Force Report: Dronkenness].

18 See note 3 supra and accompanying text.

19 See U.S. Dep't of Health, Education \& Welfare, Public Headth Service, Smoking \& Heatth: Report of the Advisory Comiar. to the Surgeon General (1964).

20 See TASk Force Report: Drunkenness, supra note 17, at 30-32. The Jellinek formula, used to produce the 4.5 million figure, has been subject to much criticism (imcluding criticism by Jellinek himself) by those who contend that it under-reports alcoholism. Id. at 31 .

21 There are probably about 100,000 narcotic addicts in the United States. See note 35 infre and accompanying text. It is estimated that there are 250,000 alcoholics in the San Francisco Bay Area. State of California, Dep't of Public Health, Div. of Alcoholism, Cirrhosis Death, Estimated Number of Alcoholics and Rate per 100,000 Population, California Three Year Average, 1962-64 (undated fact sheet).

22 See TASK Force Report: Drunkenness, supra note 17, at 37-39.

23 See id. at 121.

24 See id. at 4, 40-42.

25 "Two million arrests in 1965-one of every three arrests in America-were for the offense of public drunkenness. ..." 
fenses. ${ }^{26}$ Alcohol use generates other enormous costs to society in the form of absenteeism and job loss, marital disruption, and welfare costs.

Sedatives, stimulants, and tranquilizers are used by at least ten million Americans, many of whom are in the middle and upper socioeconomic groups and over thirty. There are probably several hundred thousand "abusers," including persons having barbiturate addiction and amphetamine psychosis. ${ }^{27}$ These drugs are primarily obtained through doctors who often prescribe them rather loosely in large quantities for nonspecific conditions. Under federal law, such prescriptions can be refilled only five times and only over a maximum six-month period..$^{28}$ There is a much less extensive but significant use and abuse of these drugs, particularly amphetamines such as methedrine, by young people who obtain it on the black market. As might be expected, the activities of the young have received disproportionate attention. Probably most of the use of these drugs in American society is for a nonspecific or even ill-advised purpose, in other words "misuse."

Marijuana, although receiving far more attention, actually ranks far below both alcohol and nicotine in terms of illicit drug use and abuse or other problems. The dried leaves of the female cannabis sativa plant, which in the form of cigarettes we call marijuana, are currently smoked, for the most part occasionally and irregularly, by many Americans in all socioeconomic classes and occupational groups. ${ }^{20}$ Several decades ago when many of the present marijuana laws were enacted, marijuana use

\footnotetext{
"The two million arrests for drunkenness each year involve both sporadic and regular drinkers." TASK FORCE RePORT: DRUNKENNESS, supra note 17, at 1.

$28 \mathrm{Id}$. at 40.

27 See The Drug Scene, supra note 16, at 22, col. 2; Presment's Conar's on Law Enforcemant and Admmistratton of Justice, Task Force Report: Narcotics and Drug ABUSE 29, 30, 33, 34 (1967) [hereinafter cited as TASK ForCE REPORT: Narcotics AND DrUo ABUSE]. These figures do not include the massive use of the mild stimulant, caffeine-in the form of coffee, tea, and cola drinks-but this must also be considered when examining the pattern of use and abuse of mind-altering drugs. Also not included in the above figures is the enormous use of over-the-counter, nonprescription substances whicb are widely advertised as being sedatives, stimulants, or tranquilizers. These preparations, usually containing such ingredients as antihistamines, aspirin, or belladonna, have either a placebo or nonspecific effect.

28 Compare Act of July 15, 1965, Pub. L. No. 89-74, § 3(b), 79 Stat. 227, 230, with 21 C.F.R. \& 166.3 (Supp. I 1966).

20 There is no reliable estimate of the prevalence of marihuana use. To the limited extent that police activity is an accurate measure, use appears to be imcreasing. . . . Marihuana use apparently cuts across a larger segment of the general population than does opiate use, but again adequate studies are lacking. . . . There are many reports of widespread use on campuses, but estimates that 20 percent or more of-certain college populations have used the drug cannot be verified or refuted.

TASK Force Report: NARcotics and Drug AdUSE, supra note 27, at 3 . The author believes that marijuana users in the United States may number one million or more.
} 
was concentrated mainly among certain "outgroups" in American society: Negroes, Mexican-Americans, jazz musicians, Bohemians, and intellectuals. But as a direct consequence of the extremism of the laws and their enforcement, the sensationalizing of the drug by drug police and mass media, the mculcation of the habit of cigarette smoking by the tobacco industry, and the general strong pressures to use mind-altering drugs in our society, the pattern has shifted enormously. Persons between eighteen and thirty are now the primary users of marijuana, but there is also considerable use among older age groups. ${ }^{30}$ Selective enforcement of the law causes undue public emphasis upon marijuana use among certain groups such as "hippies," high school and college students, Negroes, and Mexican-Americans, but this is a very unrepresentative samphing of the total picture.

The kinds of abuses associated with such drugs as alcohol and nicotine have not been observed with marijuana, although if research had not been prevented by the dictatorial policies of the Federal Bureau of Narcotics and local narcotics agencies, we would have a much fuller picture. In any case, in view of marijuana's widespread use by so many people for so many years and the apparent absence of any problems other than those manufactured by our present policies and their supporters, it can be said that the main abuse associated with marijuana comes from the destruction of the lives of those thousands of young people who are branded as criminals. Survey data from high schools and colleges in urban areas indicate that illicit use of marijuana, like illicit use of alcohol and ricotine, is both widespread and increasing among students. ${ }^{31}$ This information has many social implications for the future. Marijuana has become symbolic of the generation gap and of the conflict between young and old. If present trends towards extremism and polarization of thinking continue, the generations will be driven even farther apart, and an increasing number of young people will be driven from full participation in society.

The LSD-type drugs, particularly LSD itself, have probably been tried by at least a million people, but are probably being used with some degree of regularity by ouly some tens of thousands of mostly young,

30 Mrs. Garnet Brennan, 58-year old principal of a grade school in Nicasio, California, was fired from her job after openly admitting that she had been smoking marijuana almost daily for 18 years. Mrs. Brennan had an excellent 30-year record of teaching, is a homeowner in suburban Forest Knolls, and has always been highly regarded by friends, neighbors, and associates. Her admission was in the form of an affidavit which was one of hundreds being collected by defense attorneys representing a Marin County resident charged with the sale of marijuana. See Berkeley Barb, Oct. 20-26, 1967, at 7, cols. 1 \& 2, and at 14, cols. 1 \& 2; San Francisco Chronicle, Nov. 3, 196\%, at 3, col. 6. One wonders how many others in Mrs. Brennan's age group use marijuana but fear admitting it.

81 See TasK Force Refort: Narcotics and Drug AbUse, supra note 27, at 3. 
intellectually or mystically inclined middle-class youth. Almost all of the use of the LSD, psilocybin, mescaline (peyote), and DMT (dimethyltryptamine) is nonmedical and illegal. ${ }^{32}$ However, the use of some of the newer synthetic "psycliedelics," such as STP and MDA, does not violate the criminal law. Because isolated instances of abuse associated with LSD have been so sensationalized-a variety of crimes and psychotic beliavior liave been attributed to it -and because users liave been driven underground and made afraid to seek lielp, it is very difficult to assess the extent of abuse counected with the LSD family of drugs.

The four main categories of LSD abuse are (1) acute panic reactions which ordinarily subside when the drug effect wears off in the course of ten to twelve lours; (2) recurrence of LSD-type perceptual plienomena for brief periods (usually seconds), weeks, or inonths after the original "acid" experience; (3) prolonged schizoplurenic psyclioses requiring weeks or months of hospitalization - a phenomenon which seems to occur only in individuals who already were overtly or latently schizoplirenic; and (4) rare accidental or suicidal death while under the drug's influence. ${ }^{33}$ The incidence of these various abuses probably ranges from about one in one thousand "trips" to one in ten thousand "trips." 34 Those abuses which have, through distorted accounts, received the most extensive public attention-death and psycliosis-occur mucli more frequently in connection with alcohol, barbiturates, and cigarettes, not to mention such nondrug causes as guns and disturbed family lives.

The phenomenon whicl has come to be referred to as "dropping out" is associated in many minds with LSD, but this concept is very vague and is frequently applied to any individual who deviates from a pattern of forty hours work in a five-day week at a traditional type of job or who questions the cherished values and traditions of established society. Probably no one has "dropped out" solely as a result of using LSD; it is more likely that individuals already frustrated with the society around them

${ }^{32}$ See note 14 supra. Another and quite different pattern of use of this family of drugs (not included in the estimates in the text) is the use of peyote in religious ceremonies by Indian members of the Native American Church, discussed in W. LABARRE, Tre PEYote Cutr (1964).

33 These abuses have been compounded and complicated by the laws used to deal with LSD-type drugs; they have brought about the use of impure black market drugs which are often inadequately prepared and which often have an unknown dosage; furthermore, they lead to surreptitious use of the drugs without screeming or guidance by trusted and experienced persons. As in the case of marijuana, one significant abuse is the branding of users as criminals.

34 See generally, S. Conen, The Beyond Wirmen: Tye LSD Story (1964); Cohen, $A$ Classification of LSD Complications, Psychosomatrcs, May-June 1966, at 182; Cohen, Lysergic Acid Diethylamide: Side Effects and Complications, $130 \mathrm{~J}$. Nervous aNd MENTax DISEASE 30 (1966). 
have, in conjunction with LSD use, disaffiliated themselves from conventional society.

Millions of Americans use narcotic drugs such as morphine, codeine, Percodan, and Demerol for temporary relief of coughs and pain. With the exception of cougl syrups whicli are easily bought over the counter, this use is by special prescription from a doctor. There is also considerable misuse of these drugs, medical addiction by hundreds of thousands who have severe injuries or terminal illness with pain, and widespread abuse of headache remedies and cough syrups containing narcotics. The number of illicit or illegal narcotic addicts in the United States, using mostly heroin, is probably about one hundred thousand ${ }^{35}$ The majority are young Negro, Mexican, or Puerto Rican Americans of culturally deprived backgrounds who have grown up in urban slum ghettos, where crime is common and drugs are available at an early age. ${ }^{36}$ Because narcotic drug laws have driven the drugs and their users underground, enabling the underworld to charge exhorbitant prices, most heroin addicts are heavily involved in crimes against property to support their expensive "habit."

A tremendous variety of miscellaneous substances are also being used for mind-alteration, mostly by children and young adults. These substances include asthma and cold inhalers, the belladonna or scopolamine in over-the-counter "sedatives," the nitrous oxide in deodorant and shaving cream aerosol cans, the fumes of glue and gasoline, nutmeg and other spices, morning glory and other plant seeds, and a great diversity of other natural and synthetic drugs and substances. ${ }^{38}$ It should be clear from this that politicians, police, newspapers, and others who characteristically misuse this issue to benefit themselves, will have almost unlimited opportunities in the future to misdirect society's resources by enacting more criminal laws instead of attacking the real problems.

\section{IV}

THE REAT SOCLAL PROBLEMS: THOSE CAUSED BY DRUG ABUSE AND BY DRUG POLICIES

The most serious and least discussed social problem resulting from mind-altering drug use in American society is misuse of individual abilities, energy, time, and money. The indirect as well as direct glorification

35 See TASK Force Report: NARCOTICS AND DRUG ABdSE, supra note 27 at 2, 47-48. The estimates $i d$. at $47-48$ refer to opiate addicts; since neither cocaine nor marijuana is addictive, see $i d$. at 3 , narcotic addiction is synonymous with opiate addiction.

${ }^{38}$ See id. at 48-50.

37 See id. at 55-57.

$88 \mathrm{See} i d$. at 36 . 
of mind-altering drugs by the press, advertising media, police, and parents, the ready availability of many of these drugs, the hedonistic tendencies in our society, and the widespread alienation of young and old have brought us to our present predicament: Millions of Americans are unable to find meaning or purpose in life, to be happy, or to relate to other human beings without using drugs.

The enforcement of laws pertaining to the use of mind-altering drugs diverts financial resources, personnel (police, district attorneys, judges), and prison facilities from dealing with rapidly increasing real crime such as murder, rape, and theft; ${ }^{39}$ it diverts attention from the more crucial problem of distribution and sale of these drugs (such as marijuana or heroin from Mexico); and it precludes giving adequate emphasis to the major drug being abused, alcohol. Furthermore, the efforts to deal with drug use hampers society in combatting far more important social problems such as poverty, disease, racial discrimination, and war.

Our rulemakers' official disapproval of drug use, reminiscent, perhaps, of the Romans' use of bread and circuses, serves as a valuable smokescreen for obscuring more difficult matters. In a related fashion, laws against drug use-particularly those dealing with marijuana-provide a convenient device for attacking youth and stifling dissent and nonconformity. The unjust treatment of youth and other minority subcultures is a major social problem, breeding crime, hypocrisy, and anarchy, and driving thousands from meaningful participation in society. For both sides in this conflict between generations, drugs such as marijuana have taken on harmful symbolic importance.

Problems resulting directly from the use of mind-altering drugs include dangerous or antisocial behavior on the one hand and illness or death on the other. In the former category, it is most often alcohol, among drugs, which causes or contributes to accidents, violence, and crime. Guns and mental illness also play prominent-yet generally ignored-roles. Acute or chronic excessive use of alcohol and nicotine-the most freely distributed and least condemned mind-altering drugs-is the most prominent

39 See Kadish, The Crisis of Overcriminalization, 374 ANwars 157, 163-65 (1967). "Excessive reliance upon the criminal law to perform tasks for which it is ill-suited has created acute problems for the administration of criminal justice. The use of criminal law to enforce morals . . . has tended both to be inefficient and to produce grave handicaps for enforcement of the criminal law against genuinely threatening conduct. ... [I]t has served to reduce the criminal law's essential claim to legitimacy by inducing offensive and degrading police conduct, particularly against the poor and subcultural, and by generating cynicism and indifference to the criminal law. It las also fostered organized criminality and has produced, possibly, more crime than it has suppressed." Id. at 157. Professor Kadish served as a General Consultant for the President's Commission on Law Enforcement and Administration of Justice and is presently Reporter for the California Joint Legislative Penal Code Revision Project. 
form of drug use associated with illness, disability, and death. In addition, thousands of accidental and suicidal deaths occur each year in this country from overdoses of barbiturates, chloral hydrate, and Doriden or other narcotic and sedative drugs, often taken in combination with alcoliol. LSD-type drugs and amphetamines play only a relatively minor role in causing direct plysical harm to users and in causing or inducing them to engage in harmful behavior; their greatest abuse effect is in producing disabling psychoses. ${ }^{40}$

The drastic interference with, even prohibition of, treatment of drug abusers ranging from alcoholics through narcotic addicts is another much neglected social problem stemming from our present legal policies. In many states doctors are expected to violate medical ethics by reporting narcotic users to the police; and in some states, such as California, proper treatment of the addict is barred by a law specifying that narcotics can only be administered in certain closed institutions and only for limited periods of time. ${ }^{41}$ Professionals seeking to rehabilitate drug abusers are so stigmatized that they often turn to less controversial and more lucrative problems. Some doctors are even afraid to provide the proper amount of narcotics for a patient in severe pain. Furthermore, important research of great potential benefit to society is made difficult or impossible by present state and federal laws and regulations, particularly in regard to marijuana and LSD. ${ }^{42}$

\section{CONCLUSION}

The social and legal poicies ostensibly developed to control or prevent the use of mind-altering drugs are the cause of the main social problems arising from their use. These policies have been markedly ineffective, irrational, and harmful. The wrong drugs are receiving most of the attention; alcoliol and micotine are seriously undercontrolled and overavailable. Present laws are directed at the wrong phase of the cycle of promotion, distribution, and use. Manufacture and distribution of all mind-altering drugs-including alcohol and tobacco-should be reduced by the application of civil and crimmal penalties; advertising of these drugs should be completely banned and all products containing them prominently labeled as dangerous to health and safety. Discretion to grant probation, parole, and suspended sentences for drug offenders should be reinstituted. Research and treatment by physicians should be fully permitted and in fact encouraged. The most urgently needed reform is to

40 See Tast Force Report: Narcotics and Drug Abuse, supra note 27 , at $27,30-31$.

41 CAT. HEALTH \& SAFETY Code $\$ \S 11390-96$ (West 1964).

42 But see Artz. Rev. Stat. Ann. \& 32-1968 (1956); Cat. Headte \& Safety Code § 11916 (West Supp. 1967); N.Y. MentaL Hycrene LAW \& 229 (McKinney Supp. 1967). 
take out of the criminal law the "status crime" of being a user or possessor of a particular drug and to concentrate instead on antisocial behavior and on the phases mentioned above.

In keeping with a humanistic concept of life we should primarily concern ourselves with human beings, who for a variety of sociological and psychological reasons use drugs. We are giving the drugs themselves undue attention. Those who abuse drugs should have available long term, comprehensive outpatient public health programs of treatment and education such as San Francisco's Center for Special Problems, founded by the author. Educational programs designed to present the objective facts about the full context of these drugs including the potential risks involved in their use should be made available to students-including those in elementary school-and to the general public, to desensationalize and demythologize alcohol, marijuana, and the rest. The Federal Bureau of Narcotics and other drug pohice agencies should be closed and their agents redeployed to deal with the real problems described above. ${ }^{43}$

Finally, we must attack the roots of drug use and abuse which are deeply imbedded in a sick, corrupt, and hypocritical society. We must turn our attention from symptoms or branches of problems to the task of improving the quality of American he, facilitating the pursuit of excellence and encouraging individuality. When life itself becomes a mind-expanding experience, drugs will become relatively unimportant in our society.

${ }^{43}$ Cf. Presments Advisory Comar's on Narcotics \& Drug Aduse, Final Report 31-37 (1963). 